\title{
Sustainable strategies for improved regulatory compliance within the food-processing sector
}

Michael O. Fagbohungbe PhD

Research Associate, School of Computing, Engineering and Physical Sciences, University of the West of Scotland, Paisley, UK; Baxters Food Group, Fochabers, UK (Orcid:0000-0003-0133-4400)

Andrew S. Hursthouse PhD

Professor, Environmental Geochemistry, School of Computing, Engineering and Physical Sciences, University of the West of Scotland, Paisley, UK (Orcid:0000-0003-3690-2957)

Jan Miller MSC

Lecturer, School of Health and Life Sciences, University of the West of Scotland, Paisley, UK (Orcid:0000-0002-9153-3640)

\author{
Graeme Morrison \\ Director, European Supply Chain \& Fochabers Site, Baxters Food Group, \\ Fochabers, UK \\ Mark Stockwell \\ Manager, Environmental Waste, Baxters Food Group, Fochabers, UK \\ Iain McLellan PhD \\ Senior Lecturer in Environmental Chemistry, School of Computing, \\ Engineering and Physical Sciences, University of the West of Scotland, \\ Paisley, UK (Orcid:0000-0001-5137-6321) (corresponding author: iain. \\ mclellan@uws.ac.uk)
}

Food producers are challenged to develop and adopt reliable processing techniques to meet environmental regulations for discharge compliance. This is a logistical and technical challenge given that many food companies produce a wide range of commodities resulting in a constantly changing effluent stream. This study investigates the impact of developing, and adopting, more sustainable food-processing strategies through development of a wastehandling strategy that focuses simultaneously on waste prevention initiatives, opportunity for water reuse and optimisation of wastewater management to develop sustainable treatment processes. The results highlight the significance of different stages of waste generation within the production lines and opportunities for prioritising waste prevention by way of remanufacturing and redistribution. Food waste prevention practices allowed the diversion of more than 3-6 metric t/day of edible food to a secondary product as animal feed. Water reuse was validated by monitoring at four locations in the site for both physicochemical and bacteriological parameters. Wastewater treatment operations were monitored, and optimisation led to a reduced dependence on caustic buffering by $40 \%$, and $100 \%$ substitution of carbon supplementation from in-process sources. Water reuse strategies resulted in $200-500 \mathrm{~m}^{3} /$ day of water to be repurposed on site to reduce the volume of wastewater discharge.

\section{Introduction}

Water is a major component in the food-processing sector and is used in key operations such as sieving, washing, de-skinning, blanching, cleaning and other processing activities (Chen et al., 2019). Globally, the food production sector contributes to $19 \%$ of all human water use which if not managed efficiently can result in localised water scarcity (Ajiero and Campbell, 2018; Guimarães et al., 2018; Lee and Okos, 2011). The traditional approach to wastewater treatment has focused on advancing 'end-of-pipe' technology to treat effluent before it is discharged to the water environment. Different technologies such as lagoons, aerobic treatment, filter media and membranes have been developed with full-scale implementation to ensure effluents meet the regulatory requirements for discharge into the environment (Singh et al., 2015). Although these technologies are functional in treating contaminated wastewater, they come at a substantial operational cost (Pous et al., 2020).

With increasing awareness of global problems of water scarcity (Garcia-Garcia et al., 2019), the need to improve the sustainability of food production and wastewater treatment strategies is more pressing than ever. This can be achieved through modifications to in-house resource reuse and recovery strategies ensuring that treated effluent can be safely released to the environment (Hidalgo and Martín-Marroquín, 2019) as well as minimising food ingredient and product loss, reducing total water use and reducing demand for waste management. Improvement of the effectiveness of wastewater treatment results in decreased operational pressures, and ultimately the costs of operating the wastewater treatment plant, eliminate the risk of regulatory non-compliance and improve the overall efficiency of the processing facility.

Water abstraction for production line activities can be decreased by re-using the water in non-contact processes such as cooling, heating, pasteurising and cleaning (Barbera and Gurnari, 2018). The composition and quality of raw material, production equipment (e.g. leaks and food waste) and multiple processing operations (cleaning, heating, packaging and storage) all contribute to waste generation (Cecchi and Cavinato, 
2019; Nerín et al., 2016). Noukeu et al. (2016) highlight that the quality of wastewater depends on both the downstream treatment facilities and the upstream process for food handling, processing, packaging and storage. The food-processing industry, in particular, consumes an extensive amount of raw material (food ingredients) and water (Lee and Okos, 2011). Companies must be responsive to market opportunities and be able to adapt production to be able to rapidly adjust to meet customers' needs, an approach that is well known to many manufacturing sectors operating in ever-growing global markets (Ghanei and AlGeddawy, 2016). There is, however, a broad failure to address sustainability issues (Brunoe et al., 2019).

Sustainability in food processing means adopting a system that protects the environment and consumers' safety and conserves natural resources and energy use while maintaining food quality (Beddington, 2011). This can be approached through the use of appropriate standard operating procedures (SOPs) and the introduction of a waste prevention strategy (Albizzati et al., 2019; Niero and Rivera, 2018). The general strategies for establishing waste prevention are through redistribution, reconditioning, remanufacturing and reuse of input materials (Garcia-Garcia et al., 2019; Garrone et al., 2014; Papargyropoulou et al., 2014). Introduction of more sustainable 'upstream' processes will ultimately alter the composition of effluent and a decrease is observed in common wastewater contaminants such as nitrates $\left(\mathrm{NO}_{3}{ }^{-}\right)$, nitrites $\left(\mathrm{NO}_{2}{ }^{-}\right)$, ammonium $\left(\mathrm{NH}_{4}{ }^{+}\right)$, phosphates $\left(\mathrm{PO}_{4}{ }^{3-}\right)$ and other regulated parameters such as $\mathrm{pH}$, biological oxygen demand (BOD), chemical oxygen demand (COD) and suspended solids (SS). The food production industry must aim to have a low-cost downstream operation that is capable of meeting the regulatory discharge consents to protect aquatic ecosystems (Williams et al., 2019).

This study demonstrates an approach to link improvements in the upstream production process to reduce the demand for wastewater treatment through effective water and resource management. This was achieved by $(a)$ proactively reviewing the current processing practices within a food production company, $(b)$ the introduction of a new monitoring approach and $(c)$ the identification and implementation of improved downstream operations to treat effluent. This resulted in more sustainable and resilient operating processes across the site reducing the operational footprint and environmental risk.

\section{Methods}

\subsection{Sample collection}

The case study is based on the Baxters Food Group (BFG) operation in Scotland. The company has a multinational operation with seven sites across Europe, America and Australasia; at this site production focuses on pastries, pickled products and soup. The result is a heterogeneous effluent stream that changes daily and seasonally. The overall production process is a combination of different activities such as steam-peeling, blanching, heating, washing and packaging to generate about of 300-400 cans or jars of product per min (Figures 1 and 2). This multi-process operation has the potential to capture waste and the implementation of several strategies to make production more robust and the site operation more environmentally sustainable.

Data on the production of food waste, water reuse and effluent quality were collected and analysed between 2014 and 2015. Food waste generation points were identified from the production lines and quantities were recorded. Water samples were collected from stages that had potential for reuse: pasteuriser and rotamax (both are pasteurising units), sterimatics (sterilises low-acid foods) and cooling tower (removes process heat and lowers the temperature of the working fluid) (Figure 2). For effluent treatment, samples were collected from the components of the wastewater treatment plant: balance tank, biofilter, sump, dissolved air flotation (DAF) and final clarifier (Figures 2 and 3).

\subsection{Analytical procedures}

Effluent samples were analysed for BOD, COD, nitrate, nitrite, ammonium, SS, total suspended solids (TSS), total oxidised nitrogen (TON), volatile suspended solids (VSS), phosphate, dissolved oxygen (DO) and $\mathrm{pH}$. Water samples were collected weekly from four different reuse points and analysed for $\mathrm{pH}$, chlorine and coliforms. The wastewater samples were collected daily at every stage of treatment for the sampling period.

All analyses were carried out at the site laboratory facility except for BOD that was contracted to an external laboratory. Physicochemical and microbiological analyses were carried out according to the methodologies described in the Standard Methods for the Examination of Water and Wastewater (APHA, 2012) namely: (a) enzyme-substrate coliform test procedure, $(b)$ diethyl paraphenylene diamine indicator for chlorine, $(c)$ electrometric method for $\mathrm{pH},(d)$ phenate method for ammoniacal nitrogen, (e) COD colorimetric determination, ( $f) \mathrm{BOD}_{5},(g)$ gravimetric determination for $\mathrm{SS},(h)$ ascorbic acid for orthophosphate, $(i)$ cadmium reduction for nitrate and ( $j$ ) diazotisation method for nitrite.

\section{Results}

The results of this study are presented as three main process areas where strategic decisions can be made to drive forward more sustainable practices; for example, there was an observation that a substantial increase in food waste was attributable to the engineering complexities of the processing lines. 


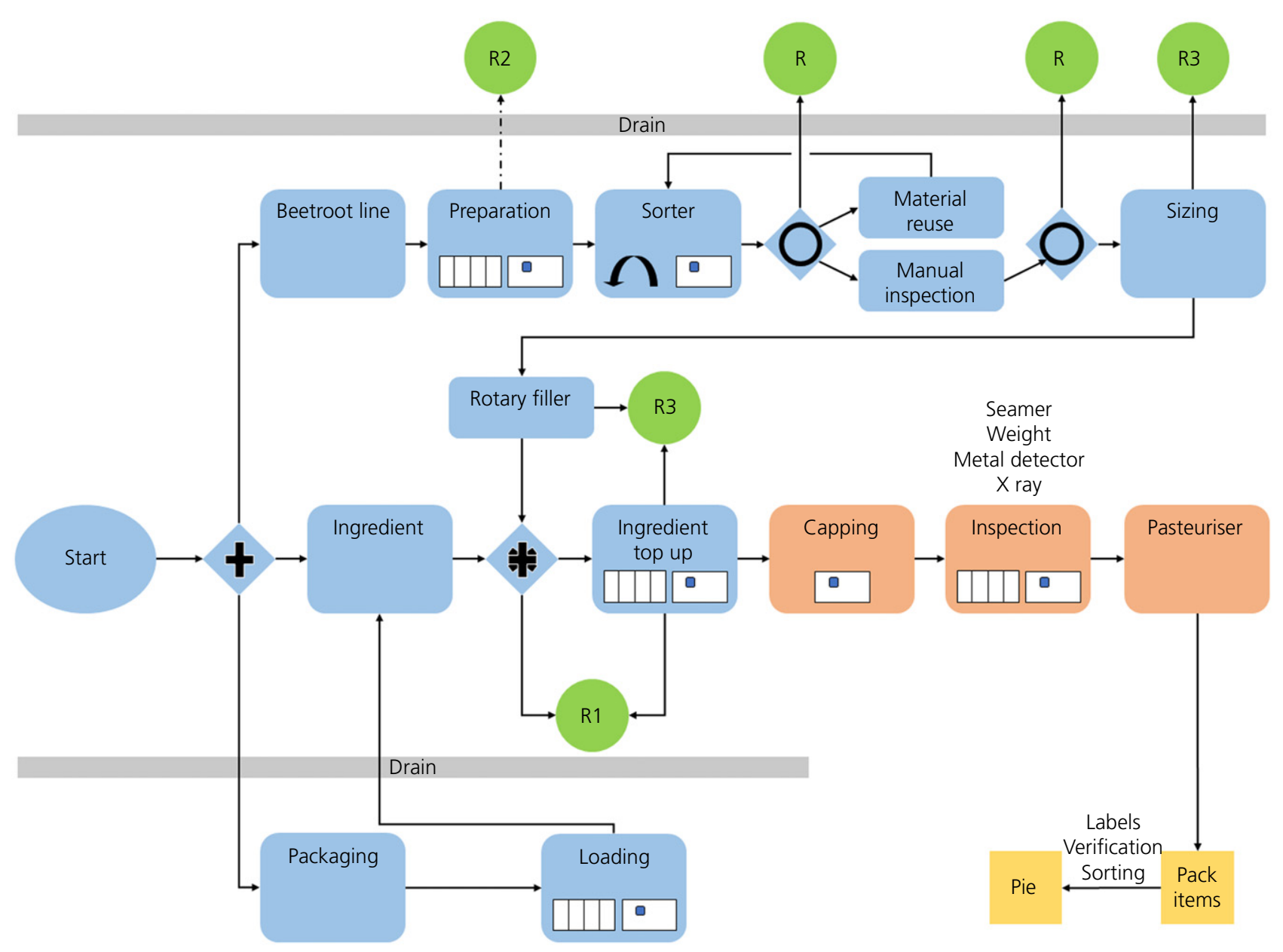

Figure 1. Schematic diagram of a manufacturing process flow (D: drain line; R: reject; R1: rework; R2: redistribution; R3: recycle)

\subsection{Food waste}

The four different production lines for processing tubers, broth and pastry exhibited potential to capture waste food (Figure 4). Within the tuber line, waste is generated at the capping, weight checking and labelling sections as quality assurance checks reject the product if it is outside the allowed weight; the capping section generated the highest amount of waste in this line at $42 \%$. Pastry waste is derived from waste flour and unused pastry trimmings during the production of pies with $32 \%$ of the waste derived from flour collected during cleaning. On the soup line, the weight checker produced the largest annual waste at $51 \%$.

\subsection{Potential for water reuse}

The physicochemical characteristics of the water pre- and posttreatment show that waste treatment provides a high level of compliance with discharge limits. The analysis of the potential for water reuse focused on pasteuriser, sterimatics, rotamax and cooling tower operation (Figure 2). The data showed that the quality of water produced at these points was suitable for indirect food-processing activity as no coliform was detected $94 \%$ of the sampling time. The water quality met the requirements for chloride and $\mathrm{pH}$ in all cases. There were seven occasions when the coliform requirement of $0 \mathrm{MPN} / 100 \mathrm{ml}$ (where MPN is most probable number) failed, values were between 50 and $4000 \mathrm{MPN} / 100 \mathrm{ml}$. In this instance, the water will be discarded as it failed the quality control guidelines of zero coliform.

\subsection{Effluent treatment}

The process monitoring of the wastewater treatment plant (Figure 5(a)) showed a reduction in the COD levels as the wastewater passes into the secondary clarifier (the final stage) decreasing from an average concentration of $3030 \mathrm{mg} / \mathrm{l}$ (balance tank) to $49 \mathrm{mg} / \mathrm{l}$ (final effluent). The result showed one instance when the discharge limit was breached for 


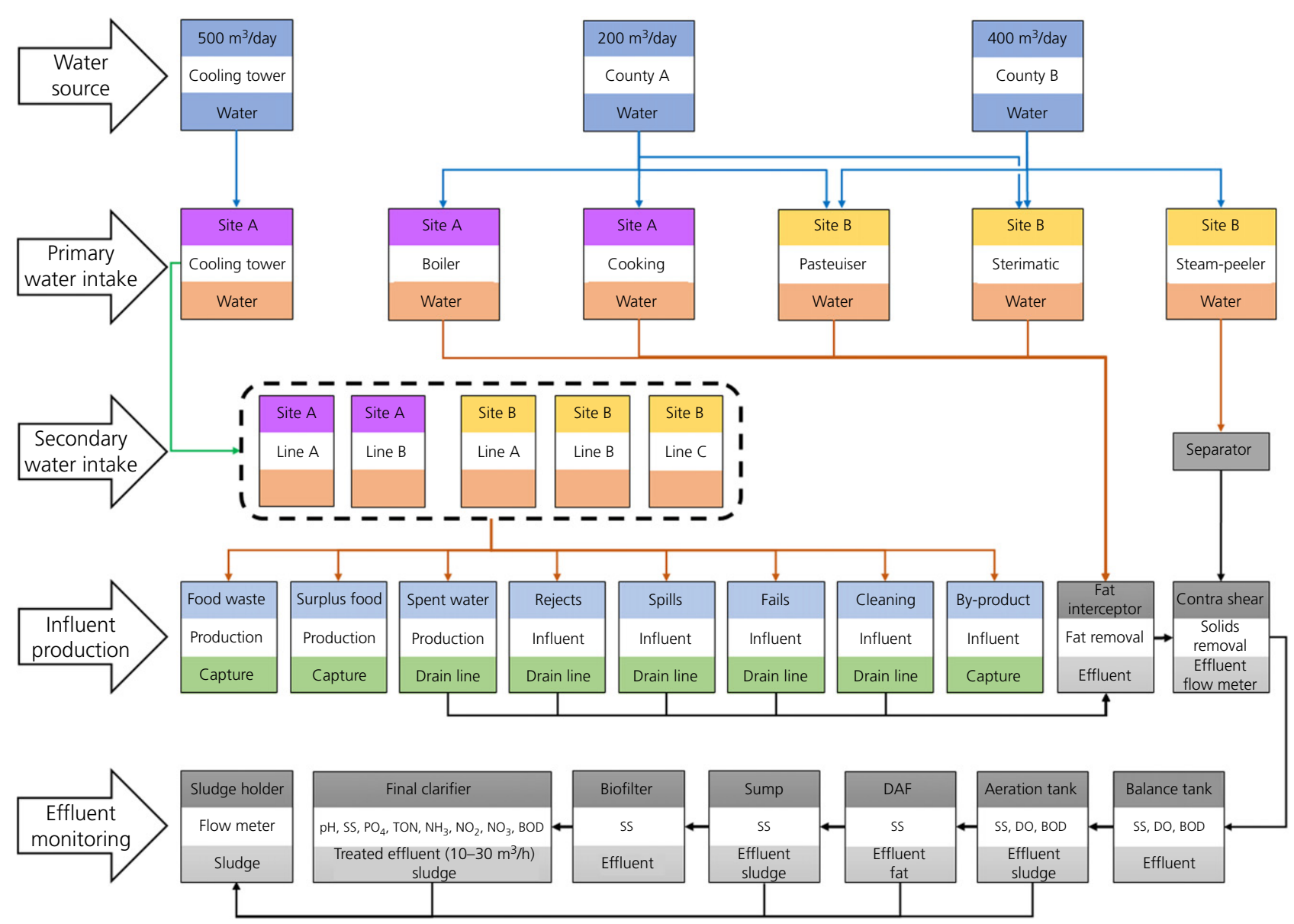

Figure 2. Schematic diagram of water distribution and wastewater treatment on site in relation to food production lines, highlighting testing points, materials' handling and waste generation (line colour: blue: potable water; orange: non-potable water; green: reused water; black: wastewater). DO, dissolved oxygen

ammonium at $42 \mathrm{mg} / \mathrm{l}$ and four instances for orthophosphate with the highest concentration of $24 \mathrm{mg} / \mathrm{l}$ (Figure 5(b)). On 20 occasions, the TON value was above the consent threshold with the highest concentration of $108 \mathrm{mg} / \mathrm{l}$ (Figure 5(b)). This trend was similar for the SS that decreased from an average concentration of 990 to $19.8 \mathrm{mg} / \mathrm{l}$ (Figure 5(c)). This can be attributed to unplanned events such as the equipment failure. When this occurs, and where the effluent quality does not meet the discharge limit, it is diverted into a holding tank for additional treatment. The wastewater was acidic with an initial average $\mathrm{pH}$ of 4.4 ; however, following treatment is neutral/slightly alkaline with a final effluent $\mathrm{pH}$ of 7.5 (Figure 5(d)).

\section{Discussion}

Analysis of the results provided a systematic and comprehensive overview of the entire operation allowing environmental and costs savings to be made by reducing waste and chemical use. These, in turn, help the natural buffering capacity of the effluent system, creating a system that is more sustainable from both the production and environmental contexts.

\subsection{Food waste}

As shown in Figure 4, all four different production lines are waste generating. Taking the tuber line as an example, the tubers are washed and steam-peeled before being conveyed into the production line. Two parallel dicing and sorting systems resize the tubers before temporary storage in the rotary filler. Clean jars are then filled with the tubers and a vinegar-based recipe before capping and pasteurisation. Figure 1 shows several stages of sequential operation required to produce a desired product and the points for high up waste prevention and valorisation strategies such as reuse and redistribution of surplus material. All production lines 


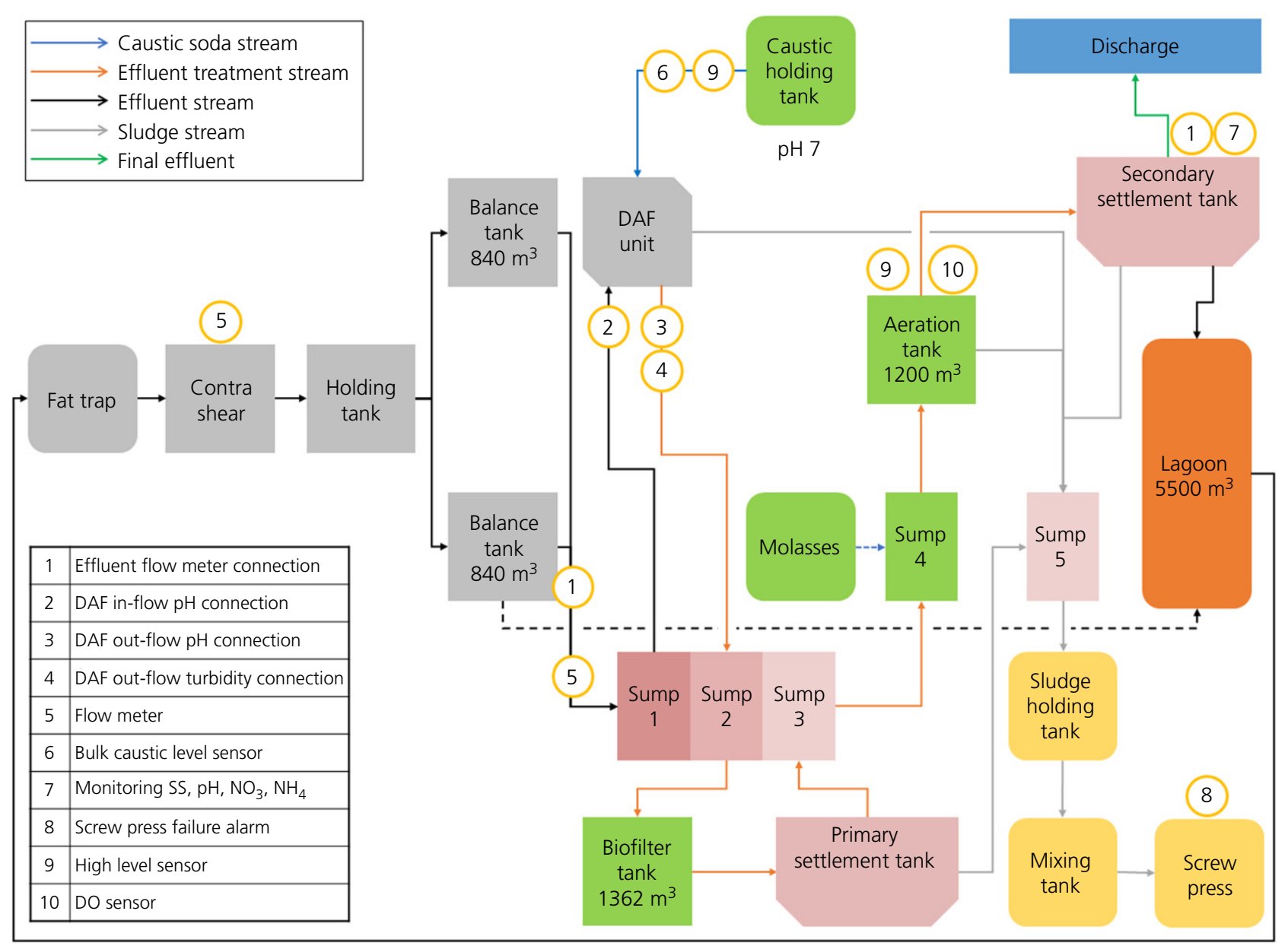

Figure 3. Schematic diagram of the wastewater treatment system at the food-processing facility. Green-coloured shapes represent processes that can be improved to increase efficiency and sustainability. DO, dissolved oxygen

follow similar processes and challenges that provide scope for waste minimisation.

Generally, food processing is expected to generate surplus material that if not properly managed becomes waste (Cecchi and Cavinato, 2019; Garrone et al., 2014; Lee and Okos, 2011). If a company takes only a material recycling approach to food waste there is still potential for pollution of wastewater by way of food disposal to drains and leakage from food waste storage reaching the wastewater drain line (Cecchi and Cavinato, 2019) with subsequently the largest impacts on COD and SS (Thomas, 2011). During this study, investigation revealed that nitrogen and phosphorus removal is not completely dealt with by material recycling, as events such as unchecked food disposal by operators not being captured or direct leakages into the wastewater drain occur. Further to this, simply re-engineering a production line to reduce food loss will not fully eliminate all material loss (Jagtap and Rahimifard,
2019). However, combining process reconfiguration with waste prevention strategies such as redistribution, remanufacturing and reuse is expected to provide significant improvement in waste generation (Lebersorger and Schneider, 2014).

\subsection{Upstream processing}

Prior to the case study, food waste management has been predominantly through material capture and recycling. However, by adopting waste prevention strategies and developing sustainable SOPs, the environmental footprint of the production process will be reduced (Bojana et al., 2020; Chawla et al., 2020; de Sadeleer et al., 2020). To fully integrate these strategies into a production line, each stage must be assessed and upgraded to allow material capture in a way that meets the requirement for a secondary market and other alternative uses (Facchini et al., 2018; Garrone et al., 2014). Included as part of this study, waste prevention measures have been integrated within the production lines and four changes to processing 


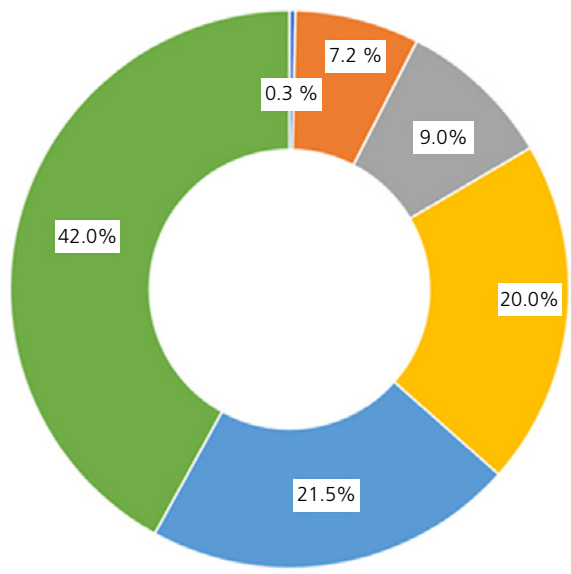

(a)

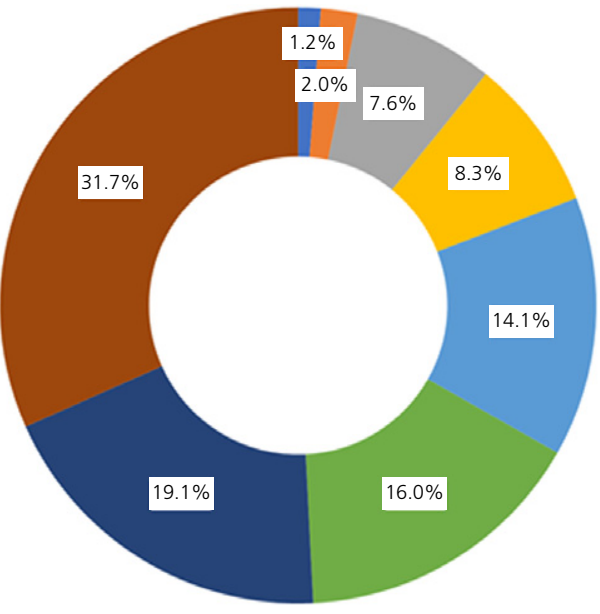

(b)

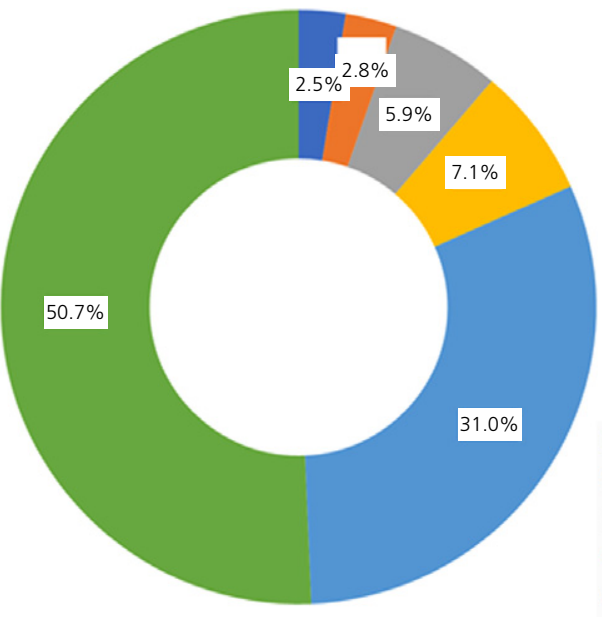

(c)

Figure 4. Annual distribution of waste at different positions on the food-processing line ((a) tuber line; (b) pastry line; (c) broth line)
Conveyor waste

- Cooker

= Inspection table

- Labeller

= Rotary filler

- Capper operation

- Meat filler = Loader - Gravy filler = Unloader = Seamer = Steriflow - X-ray inspection - Pastry floor

- Other anheel n Vegetable waste - Sterimatics = Labelling Weight checker activities were adopted: ( $a$ ) pastry trim is now captured and reused to make dough, (b) flour waste is reused as a carbon source at the wastewater treatment plant, replacing externally purchased molasses, $(c)$ vinegar waste is used for $\mathrm{pH}$ control to enhance phosphorus removal from the wastewater treatment process and, $(d)$ peel from tuber processing is captured and redistributed as animal feed. These actions have resulted in a reduction in environmental impacts from reduction in waste generated, as well as realising economic savings for dosing in the wastewater treatment system of $40 \%$ on caustic use and $100 \%$ on carbon supplement.

\subsection{Water reuse}

The data were compared with the appropriate regulatory limits for reuse and disposal; these included the urban wastewater treatment directive $(91 / 271 / \mathrm{EC}$ (EC, 1991)), water for human consumption directive (98/83/EC (EC, 1998)), foodstuff hygiene regulations (852/2004 (EC, 2004)), drinking water regulations (GoI, 2014) and the implementation strategy for the water framework directive and floods directive (EU, 2016) (all as amended).

These regulations set limits for wastewater disposal and water reuse at food production facilities but can be further adjusted by the local environmental regulator. Companies that wish to demonstrate their commitment to environmental protection can set limits that go further than the legislative requirements, an approach that BFG has taken. The daily limits set by the company to allow water reuse are: coliforms $0 \mathrm{MPN} / \mathrm{ml}$, chlorine $2 \mathrm{mg} / \mathrm{l}$ and $\mathrm{pH}$ 7. The wastewater disposal limits set by the Scottish Environment Protection Agency (SEPA) are: volume $990 \mathrm{~m}^{3}$; BOD $25 \mathrm{mg} / \mathrm{l}$; TSS $100 \mathrm{mg} / \mathrm{l}$; pH 5-9; ammonium $15 \mathrm{mg} / \mathrm{l}$; TON $30 \mathrm{mg} / \mathrm{l}$; and phosphate $12 \mathrm{mg} / \mathrm{l}$.

The four water reuse systems utilised onsite (pasteuriser, sterimatics, rotamax and cooling tower) were evaluated to determine their effectiveness on improving downstream wastewater treatments (Figure 2). Analysis of chlorine, coliform, $\mathrm{pH}$ and Escherichia coli found that chlorine was below the maximum company limit established for reuse $(2 \mathrm{mg} / \mathrm{l})$. This is an indication that the chemistry of the water was within the required threshold according to the drinking water directive (98/83/EC as amended (EC, 1998)). However, the water did fail the microbiological tests on several occasions, with the water being diverted to the treatment plant rather than re-used. It is, therefore, essential that microbiological testing (coliform count and E. coli) is included with any SOP for water reuse. Improvements in the microbiological determinants quality of process water can be achieved by installing a device to maintain zero coliforms through using ultraviolet light $\left(30 \mathrm{~mW} / \mathrm{cm}^{2}\right)$ disinfection or chlorination $(2-3 \mathrm{mg} / \mathrm{l}$ residual chlorine). 


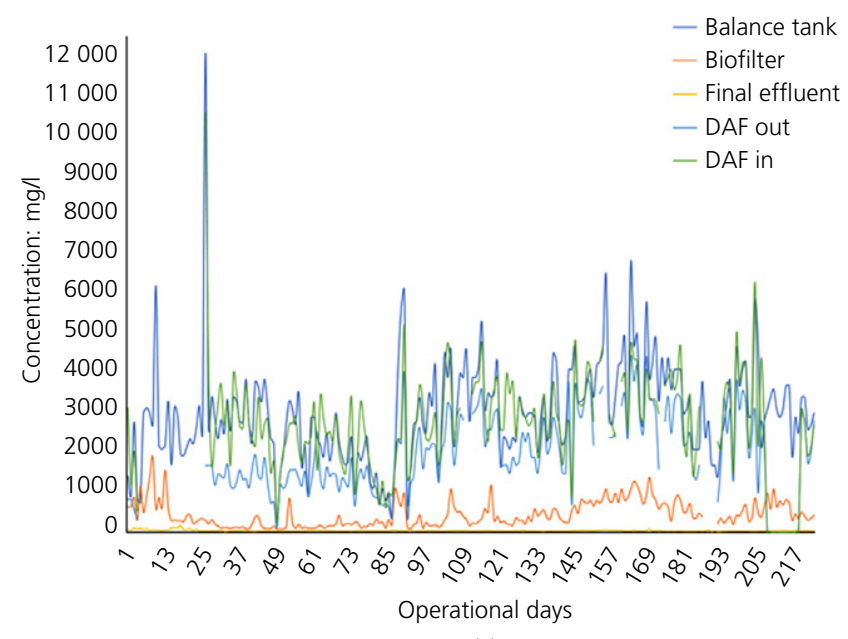

(a)

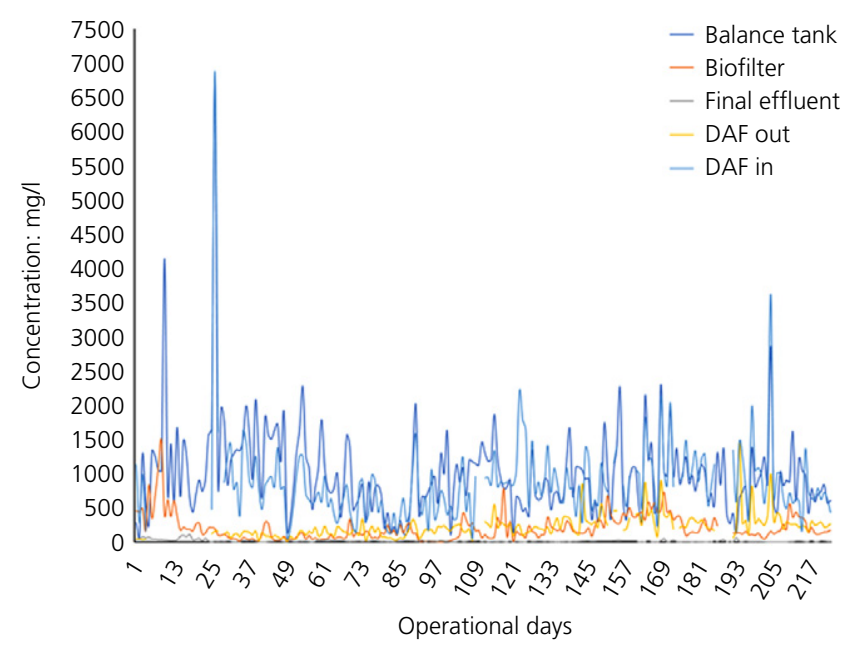

(c)

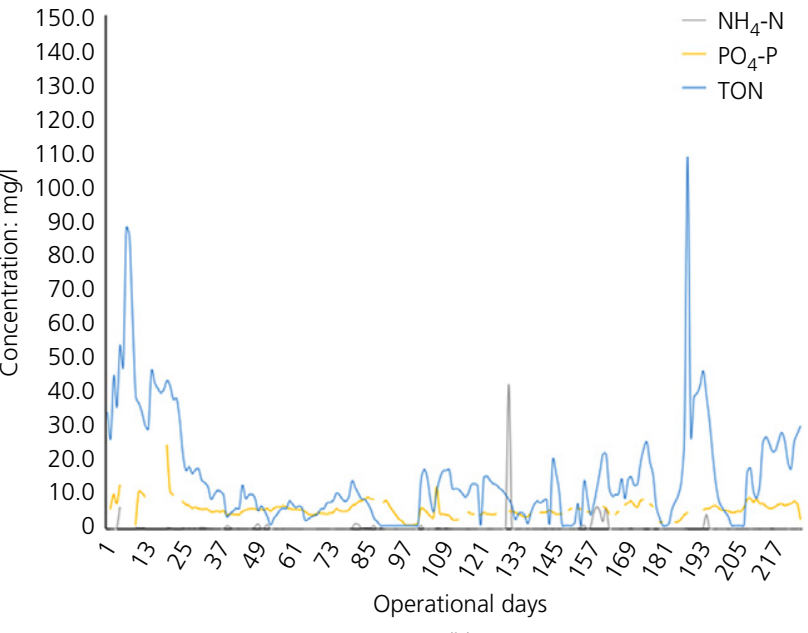

(b)

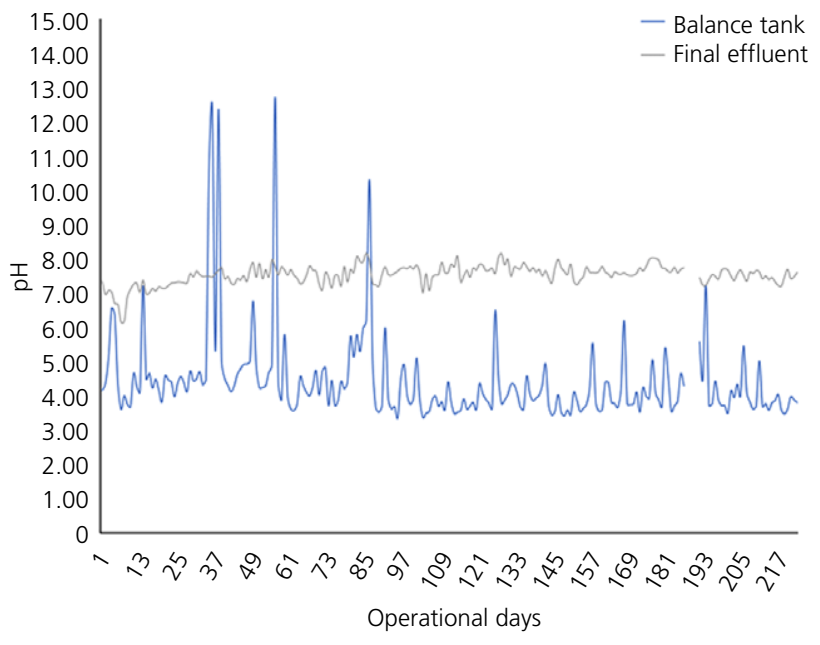

(d)

Figure 5. Characterisation of wastewater and effluent from the different stages in wastewater generation on the site for 2014-2015 ((a) COD; (b) nutrients in final effluent; (c) SS; (d) pH)

Implementing a water reuse strategy can greatly reduce water consumption by up to 30\% (Manzocco et al., 2015), and will ultimately affect the amount of effluent discharged. A few current waste reuse strategies were strengthened during the study period including the automated cleaning unit, recycled process water for cooling and heating to reduce water consumption and volume of wastewater needing treatment by $100-300 \mathrm{~m}^{3} /$ day. An average of $200-500 \mathrm{~m}^{3}$ of water per day is required to operate the cooling and heating systems (Figure 6) and it is essential that the water is re-usable to avoid disposal and strain on the wastewater treatment plant.

More sustainable water reuse can be achieved; however, it must be stressed that food hygiene and water quality needs are critical for production processes and should be balanced against the cost of achieving such quality. In addition, although water scarcity is not currently a problem in Scotland, in many countries it is and with a growing global population and climate change impacts on supply, it is important that any water reuse strategy for both potable and non-potable purposes is well defined. For non-potable reuses such as cleaning, boiler and cooling water, large volumes of water can be more easily managed as it is not required to meet stringent water quality levels (Codex, 2000).

\subsection{Wastewater treatment}

The upstream processes (raw material and processing technologies) affect the nature of wastewater generated and, given the 


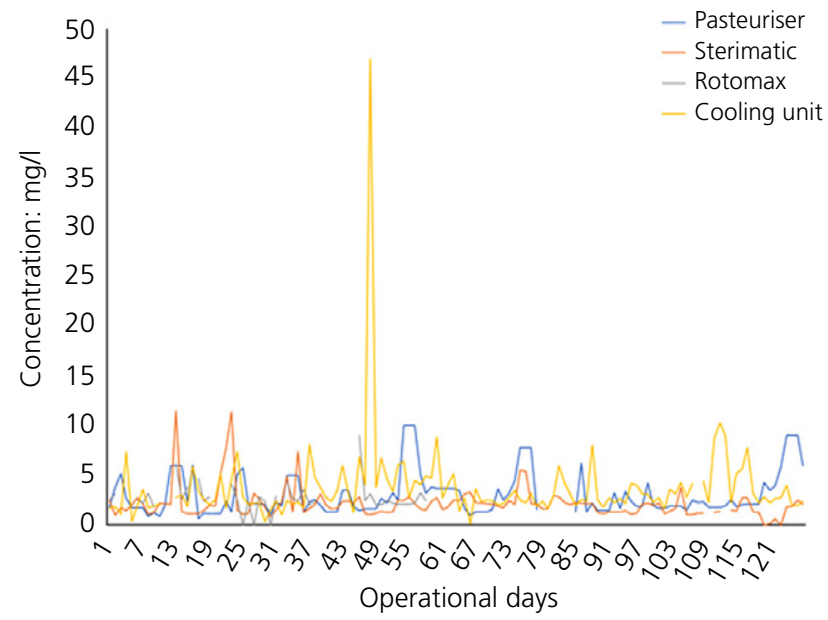

(a)

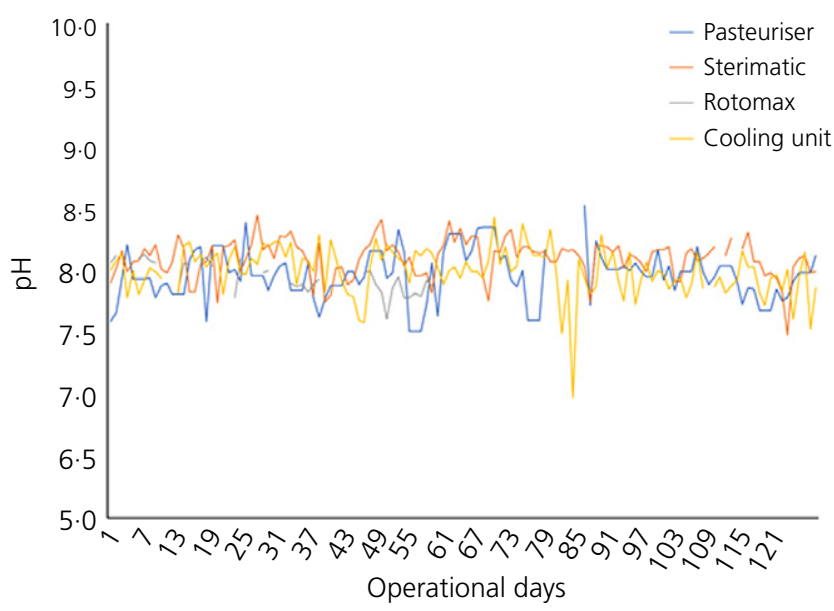

(b)

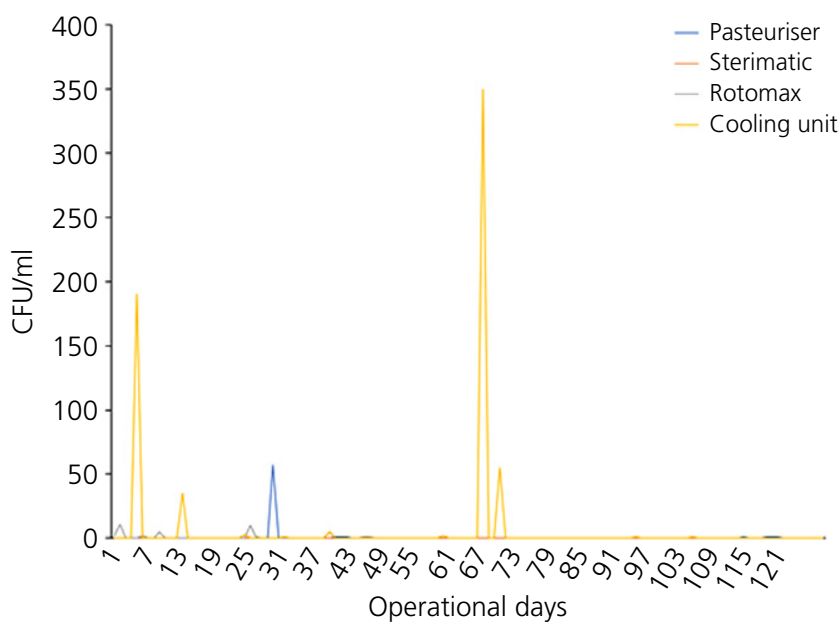

(c)

Figure 6. Characterisation of reused water at different stages of food processing ((a) chlorine levels; (b) pH and (c) coliform). The quality of reusable water for different heat treatment and cooling system is shown. Data show the suitability of the water for indirect foodprocessing activities as $\mathrm{pH}$ and chloride were $>5.5$ and $<20 \mathrm{mg} / \mathrm{l}$, respectively. CFU, colony-forming units

large variety of products manufactured on site, the quality of wastewater changes on a daily and seasonal basis. The onsite treatment technology is specific for the effluent signature and the legislative requirements for discharge consent. However, operating practice has been modified to become more sustainable. For this site, $500-800 \mathrm{~m}^{3} /$ day of wastewater is generated with a daily discharge limit of $990 \mathrm{~m}^{3} /$ day. The different processes used within the system are shown in Figure 7.

\subsubsection{Removal of solid material}

Removal of SS is an important step in wastewater treatment as it reduces the mineral and organic particles contained in the wastewater and allows the plant to maintain average COD and TSS values of 3030 and $990 \mathrm{mg} / \mathrm{l}$, respectively. Figure 3 shows that the effluent passes through a fat trap (to remove grease), a contra shear (to remove solids) and settling basin (to remove coarse solids - grit). The use of a contra shear is compared with parabolic screen filters meaning there are fewer issues of clogging (Droste and Gehr, 2018). The settling basin is useful for removing stones, grit and sand under gravity (Gerba and Pepper, 2019); within this system, solid separation is facilitated with the addition of coagulants and flocculants to concentrate SS and colloidal suspension in solution, further reducing COD to $1952 \mathrm{mg} / \mathrm{l}$ and TSS to $228 \mathrm{mg} / 1$. Settling basins are not effective against grease and scum; these can be removed using clarifiers with skimmers such as a DAF device, where a skimmer removes the flocs of solid from the top of the wastewater (Bolto and Xie, 2019). 


\begin{tabular}{|l|}
\hline Beverages \\
Biscuits \\
Oils \& fats \\
Drinks \\
\hline
\end{tabular}
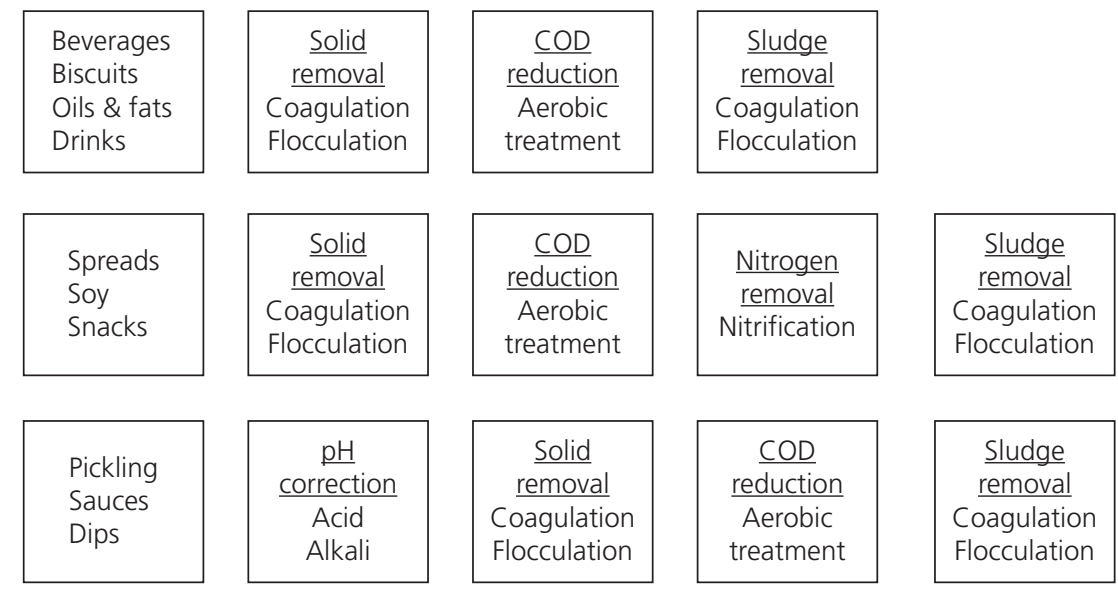

\begin{tabular}{|l|}
\hline Cheese \\
Dairy \\
Meat \& fish \\
Soup \\
\hline
\end{tabular}
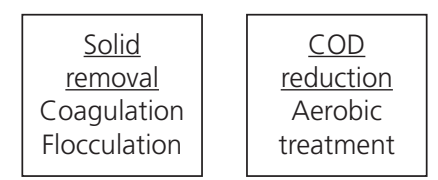
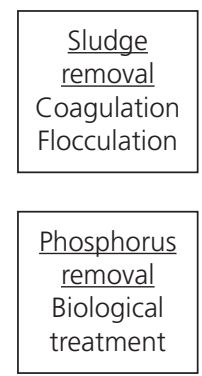

Sludge

removal

Coagulation

Flocculation

Figure 7. Production processes matched with potential wastewater treatment technologies. A range of technologies for treating wastewater are shown and how they might be integrated to match the properties of the wastewater

Biological treatment using an activated sludge tank system generates sludge consisting of clays, fine materials and dead and living cells (Tandoi et al., 2017), and removal of solid material is an essential post-biological treatment step to prevent sludge build-up. A common technique for handling sludge is to thicken it by adding a coagulant and flocculant, followed by dewatering using a screw press (Fritz et al., 2017). This technique explains why the concentration of solids in the activated sludge tank is high $(4988 \mathrm{mg} / \mathrm{l})$. Developing a more sustainable approach and the implementation of waste prevention strategies upstream would reduce the quantity of food material intercepted in the contra shear and potentially reduce the amount of flocculants used.

\subsection{2 $\mathrm{pH}$ correction}

Adjusting $\mathrm{pH}$ is an important step in wastewater treatment as it enhances the separation of dissolved solids and potentially toxic elements from wastewater (Yilmaz et al., 2019). There are two main challenges in this case study: (a) 'clean-in-place' activities (common to most food production companies) and (b) the addition of vinegar for the pickling of tubers (which is unique to the production activity in this study). 'Clean-inplace' activities relate to the washing of the interior surfaces of pipes and vessels in the production line; the cleaning product can cause fluctuation in the $\mathrm{pH}$ depending on the concentration of acid or base present in the cleaning product. A pH correction step is often administered by way of chemical dosing: sulfuric acid $\left(\mathrm{H}_{2} \mathrm{SO}_{4}\right)$ and hydrochloric acid $(\mathrm{HCl})$ are used to reduce alkalinity and with calcium, magnesium and sodium hydroxides $\left(\mathrm{Ca}(\mathrm{OH})_{2}, \mathrm{Mg}(\mathrm{OH})_{2}\right.$ and $\left.\mathrm{NaOH}\right)$ to buffer against acidity.

During the pickling and dressing processes, organic acids such as acetic acid and citric acid cause the $\mathrm{pH}$ of this system to fall outside the discharge requirement of $\mathrm{pH}$ 5.5-9.0; reaching on average $\mathrm{pH}=4$. Currently, a specific vinegar capture system is in place, which if not present would result in $\mathrm{pH}$ falling to between 3 and 3.4. Until recently, the approach has been to correct the $\mathrm{pH}$ using a $35 \% \mathrm{w} / \mathrm{v}$ sodium hydroxide; however, this is not a sustainable practice. However, given that organic acids are biodegradable, they can be neutralised during the biological treatment stage, hence eliminating the need for chemical buffers (Kumbha et al., 2014). On occasions when the effluent is more alkaline, another technique is to use sulfur or thiosulfate within a biological treatment system to facilitate acid production; this approach is often used in bioleaching of metals (Faramarzi et al., 2019).

Adopting a biological approach to $\mathrm{pH}$ correction is a more environmentally friendly, sustainable method that eliminates 
Table 1. Operational conditions for different types of biological wastewater treatment reactors

\begin{tabular}{|c|c|c|c|c|c|c|c|}
\hline Classification & Reactor type & Reactor subset & $\begin{array}{l}\text { Solid } \\
\text { retention } \\
\text { time: days }\end{array}$ & $\begin{array}{l}\text { Hydraulic } \\
\text { retention } \\
\text { time: } h\end{array}$ & $\begin{array}{l}\text { Organic- } \\
\text { volumetric } \\
\text { loading } \\
\text { rate: } \mathrm{m}^{3} / \text { day }\end{array}$ & $\begin{array}{c}\text { Food:micro- } \\
\text { organism ratio, } \\
\text { F:M: (BOD/VSS day) }\end{array}$ & $\begin{array}{l}\text { Mixed } \\
\text { liquid } \\
\text { SS: g/l }\end{array}$ \\
\hline \multirow[t]{5}{*}{ Dispersed } & Aerobic lagoon & - & - & $3-8$ & $0.1-0.3$ & $0.04-0.1$ & $3-5$ \\
\hline & Oxidation ditch & - & $15-30$ & $15-30$ & $0.1-0.3$ & $0.04-0.1$ & $3-5$ \\
\hline & \multirow[t]{3}{*}{ Activated sludge tank } & Complete mix & $3-5$ & $3-5$ & $0.3-1.6$ & $0.2-0.5$ & $1.5-4$ \\
\hline & & Extended aeration & $20-40$ & $2-4$ & $0.1-0.3$ & $0.04-0.1$ & $2-5$ \\
\hline & & Contact stabilisation & $5-10$ & $0.5-1$ & $0.5-1$ & $0.2-0.6$ & $6-10$ \\
\hline \multirow[t]{3}{*}{ Immobilised } & \multirow[t]{2}{*}{ Fixed bed bioreactor } & Submerged filter & $0.5-2$ & $1.5-3$ & $1.2-2.4$ & $1.5-4.0$ & $0.2-1$ \\
\hline & & Trickle filter & $0.5-2$ & $1.5-3$ & $1.2-2.4$ & $1.5-4.0$ & $0.2-1$ \\
\hline & Sequential batch reactor & - & $10-30$ & $15-40$ & $0.1-0.3$ & $0.04-0.1$ & $1.5-4$ \\
\hline
\end{tabular}

Source: adapted from Metcalf et al. (1972) and Samer (2015).

Table 2. Operating conditions within the activated sludge tank for different pollutants

$\begin{array}{llll}\text { Aerobic } & \text { Organic matter }+\mathrm{O}_{2}+\text { Microbes } & \rightarrow & \mathrm{CO}_{2}+\mathrm{NH}_{4}^{+}+\mathrm{PO}_{4}{ }^{3-} \\ & \text { Organic carbon }+\mathrm{NH}_{4}^{+}+\mathrm{O}_{2}+\text { Microbes } & \rightarrow & \mathrm{NO}_{3}^{-} \\ \text {Onaerobic } & \text { Organic carbon }+\mathrm{PO}_{4}{ }^{3-}+\mathrm{O}_{2}+\text { Microbes } & \rightarrow & \mathrm{Biomass}^{-} \mathrm{HPO}_{3}{ }^{-} \\ \text {Anoxic } & \text { Organic matter }+ \text { Microbes } & \rightarrow & \mathrm{CH}_{4}+\mathrm{CO}_{2}+\mathrm{NH}_{4}^{+}+\mathrm{PO}_{4}{ }^{3-} \\ & \text { Organic carbon }+\mathrm{NO}_{3}{ }^{-}+\text {Microbes } & \rightarrow & \mathrm{NO}_{2}^{-} \\ & \text {Organic carbon }+\mathrm{NO}_{2}^{-}+\text {Microbes } & \rightarrow & \mathrm{N}_{2} \\ & \text { Organic carbon }+\mathrm{NO}_{3}{ }^{-}+\mathrm{PO}_{4}{ }^{3-}+\text { Microbes } & \rightarrow & \text { Biomass }-\mathrm{HPO}_{3}{ }^{-}\end{array}$

the introduction of toxic chemicals to the environment, reduces handling risks and will reduce the cost of treatment for a business. By using this approach with the onsite biofilter the $\mathrm{pH}$ of final effluent discharge reaches $7-8$, which is well within the regulatory limit.

\subsubsection{Biological treatment}

Biological treatment is an integral part of the wastewater treatment system to remove or reduce carbon, nitrogen and phosphate (Droste and Gehr, 2018). At this site, cream and milk contribute to phosphate, the fermentation of meat contributes to total organic nitrogen $\left(\mathrm{TON}^{-}\right)$. An integrated system of a biotower, primary clarifier, activated sludge tank and a secondary clarifier are part of a biological treatment system used to stabilise the wastewater to meet COD, pH, TON, TSS and phosphate discharge requirements. The results show the degradation of the organic value (COD) between the biotower and the final clarifier to be 469 and $49 \mathrm{mg} / \mathrm{l}$, respectively.

Biotowers minimise the risk of microbial fall out, increase the food-to-micro-organism (F:M) ratio and allow companies to treat their wastewater efficiently due to the small space requirement and high throughput (Bloor et al., 1995); different technologies employed to reduce COD and other organic species present in the wastewater are shown in Table 1. The activated sludge tank is the heart of the wastewater treatment system for the removal of $\mathrm{TON}^{-}$and phosphate and operating conditions of the activated sludge tank can be adjusted to target for a specific pollutant (Table 2). Previously molasses has been added to the system to increase denitrification and phosphate removal (Figure 3); however, by developing a waste prevention strategy, other organic carbon sources from within the production process such as waste sugar, vinegar and flour have been identified as materials that could be used to drive the biological removal of nitrate and phosphate. This benefits the company by turning a waste product to a resource.

Figure 5 shows that there are times when the TON and phosphate values of the final clarifier were above average; maximum values 96 and $24 \mathrm{mg} / \mathrm{l}$, respectively. These events coincide with the periods of production shutdown and then resumption. The microbes within the wastewater system are starved during shutdown and then go into 'shock' when the flow returns as production is restarted. During these periods, there is an increased risk of non-compliance with regulatory consents. A simple solution is to store sufficient wastewater before the shutdown occurs; however, this would be impractical on a site that discharges $>500 \mathrm{~m}^{3} /$ day with an increase required in the volume of tank (in addition to the additional space and cost that will be required). A shutdown is typically for 2 weeks and the effluent storage capacity needed is not operationally sustainable. A more sustainable approach has been identified and the operating volume of the activated sludge tank will be varied to accommodate the reduced flow during shutdown by the end of 2021. This will also reduce the energy needed to aerate the tank by $120 \mathrm{kWh}$ per day. 


\section{Conclusion}

Striking a balance between compliance with discharge consent and business costs is a concern for all food-processing industries. This study has systematically reviewed the site operations, material balance and water and wastewater quality to underpin the application of a waste prevention strategy to reduce waste and improve quality of effluent. The capture mechanisms for surplus vinegar and reuse of flour waste were adopted at BFG and this resulted in a 40 and $100 \%$ reduction in the costs of caustic soda and molasses as carbon supplement, respectively. Similarly, the water reuse strategy for non-food activities helped save $100-300 \mathrm{~m}^{3} /$ day of water. It has been shown that through a detailed review and the identification of steps across the full production process, upstream and downstream operations benefit from more holistic planning and management.

By developing a waste prevention strategy, areas of improvement can be identified within the food-processing sector. Through its implementation, multiple benefits can be realised including: $(a)$ a reduction in the amount of solid waste produced, $(b)$ water reuse in processes that do not affect food hygiene resulting in lower wastewater volumes for treatment and $(c)$ specific waste materials from the production lines being utilised within the wastewater treatment plant to minimise chemical usage.

\section{Acknowledgement}

The authors acknowledge funding through Innovate UK Knowledge Transfer Partnership scheme, Project 11628.

\section{REFERENCES}

Ajiero I and Campbell D (2018) Benchmarking water use in the UK food and drink sector: case study of three water-intensive dairy products. Water Conservation Science and Engineering 3(1): 1-17.

Albizzati PF, Tonini D, Chammard CB and Astrup TF (2019) Valorisation of surplus food in the French retail sector: environmental and economic impacts. Waste Management 90: 141-151.

APHA (American Public Health Association) (2012) Standard Methods for the Examination of Water and Wastewater, 22nd edn. (Clesceri LS, Greenberg AE and Eaton AD (eds)). American Public Health Association, Washington, DC, USA.

Barbera M and Gurnari G (2018) Wastewater Treatment and Reuse in the Food Industry. Springer, Cham, Switzerland.

Beddington SJ (2011) The future of food and farming. International Journal of Agricultural Management 1(2): 2-6.

Bloor JC, Anderson GK and Willey AR (1995) High-rate aerobic treatment of brewery wastewater using the jet loop reactor. Water Research 29(5): 1217-1223.

Bojana B, Quested TE, Elin RÃ and Swannell RP (2020) The role of reducing food waste for resilient food systems. Ecosystem Services 45(C): 101140.

Bolto B and Xie Z (2019) The use of polymers in the flotation treatment of wastewater. Processes 7(6): 374

Brunoe TD, Andersen AL and Nielsen K (2019) Changeable manufacturing systems supporting circular supply chains. Procedia CIRP 81: 1423-1428.
Cecchi F and Cavinato C (2019) Smart approaches to food waste final disposal. International Journal of Environmental Research and Public Health 16(16): 2860.

Chawla G, Lugosi P and Hawkins R (2020) Evaluating materiality in food waste reduction interventions. Annals of Tourism Research Empirical Insights 1(1): 100002.

Chen $\mathrm{H}$, Zhang $\mathrm{H}$, Tian J et al. (2019) Recovery of high value-added nutrients from fruit and vegetable industrial wastewater. Comprehensive Reviews in Food Science and Food Safety 18(5): 1388-1402.

Codex (2000) Report of the Thirty Third Session of the Codex Committee on Food Hygiene. Annex I: proposed draft annex for sprout production. Codex Committee on Food Hygiene, Rome, Italy.

de Sadeleer I, Brattebø H and Callewaert P (2020) Waste prevention, energy recovery or recycling-directions for household food waste management in light of circular economy policy. Resources, Conservation and Recycling 160: 104908.

Droste RL and Gehr RL (2018) Theory and Practice of Water and Wastewater Treatment. John Wiley \& Sons, Hoboken, NJ, USA.

EC (European Community) (1991) Council Directive of 21 May 1991 concerning urban waste water treatment (91/271/EEC). Official Journal of the European Communities L135/40.

EC (1998) Council directive 98/83/EC of 3 November 1998 on the quality of water intended for human consumption. Official Journal of the European Communities L330/32.

EC (2004) Regulation (EC) No 852/2004 of the European Parliament and of the Council of 29 April 2004 on the hygiene of foodstuffs. Official Journal of the European Union L139/1.

EU (European Union) (2016) Common Implementation Strategy for the Water Framework Directive and the Floods Directive. Guidelines on Integrating Water Reuse into Water Planning and Management in the Context of the WFD. EU, Amsterdam, the Netherlands.

Facchini E, lacovidou E, Gronow J and Voulvoulis N (2018) Food flows in the United Kingdom: the potential of surplus food redistribution to reduce waste. Journal of the Air \& Waste Management Association 68(9): 887-899.

Faramarzi MA, Mogharabi-Manzari M and Brandl H (2019) Bioleaching of metals from wastes and low-grade sources by $\mathrm{HCN}$-forming microorganisms. Hydrometallurgy 191: 105228.

Fritz EW, Weinert D and Neumann H (2017) Screw press maximum dewaterability and energy consumption. Proceedings of the Water Environment Federation 2017(1): 642-649.

Garcia-Garcia G, Stone J and Rahimifard S (2019) Opportunities for waste valorisation in the food industry - a case study with four UK food manufacturers. Journal of Cleaner Production 211: 1339-1356.

Garrone P, Melacini M and Perego A (2014) Surplus food recovery and donation in Italy: the upstream process. British Food Journal 116(9): 1460-1477.

Gerba CP and Pepper IL (2019) Municipal wastewater treatment. In Environmental and Pollution Science (Brusseau ML, Pepper IL and Gerba CP (eds)), 3rd edn. Elsevier, London, UK, pp. 393-418.

Ghanei S and Algeddawy T (2016) A new model for sustainable changeability and production planning. Procedia CIRP 57: 522-526.

Gol (Government of Ireland) (2014) S.I. No. 122/2014 - European Union (Drinking Water) Regulations 2014. GoI, Dublin, Ireland.

Guimarães JT, Souza AL, Brígida AIS et al. (2018) Quantification and characterization of effluents from the seafood processing industry aiming at water reuse: a pilot study. Journal of Water Process Engineering 26: 138-145. 
Hidalgo D and Martín-Marroquín JM (2019) Adding sustainability to the beverage industry through nature-based wastewater treatment. In Processing and Sustainability of Beverages (Grumezescu AM and Holban AM (eds)), 2nd edn. Woodhead Publishing, Duxford, UK, pp 1-36.

Jagtap S and Rahimifard S (2019) The digitisation of food manufacturing to reduce waste-Case study of a ready meal factory. Waste Management 47: 387-397.

Kumbha SR, Ramanjaneyulu V and Swamy A (2014) Aerobic biodegradation of vinegar containing wastewater by mixed culture bacteria from soil in fluidised bed reactor. Journal of Energy Research and Applications 4(9): 110-113.

Lebersorger S and Schneider F (2014) Food loss rates at the food retail, influencing factors and reasons as a basis for waste prevention measures. Waste Management 34(11): 1911-1919.

Lee W and Okos MR (2011) Sustainable food processing systems-path to a zero discharge: reduction of water, waste and energy. Procedia Food Science 1: 1768-1777.

Manzocco L, Ignat A, Anese M et al. (2015) Efficient management of the water resource in the fresh-cut industry: status and perspectives. Trends in Food Science \& Technology 46(2): 286-294.

Metcalf L, Eddy HP and Tchobanoglous G (1972) Wastewater Engineering: Treatment, Disposal, and Reuse. McGraw-Hill, New York, NY, USA.

Nerín C, Aznar M and Carrizo D (2016) Food contamination during food process. Trends in Food Science \& Technology 48: 63-68.

Niero M and Rivera XCS (2018) The role of life cycle sustainability assessment in the implementation of circular economy principles in organizations. Procedia CIRP 69: 793-798.
Noukeu N, Gouado I, Priso R et al. (2016) Characterization of effluent from food processing industries and stillage treatment trial with Eichhornia crassipes and Panicum maximum. Water Resources and Industry 16: 1-18.

Papargyropoulou E, Lozano R, Steinberger JK, Wright N and Ujang ZB (2014) The food waste hierarchy as a framework for the management of food surplus and food waste. Journal of Cleaner Production 76: 106-115.

Pous N, Hidalgo M, Serra T et al. (2020) Assessment of zooplanktonbased eco-sustainable wastewater treatment at laboratory scale. Chemosphere 238: 124683.

Samer M (2015) Biological and chemical wastewater treatment processes. In Wastewater Treatment Engineering (Samer M (eds)). IntechOpen, London, UK, pp. 1-50.

Singh NK, Kazmi A and StarkI M (2015) A review on full-scale decentralized wastewater treatment systems: techno-economical approach. Water Science and Technology 71(4): 468-478.

Tandoi V, Rossetti S and Wanner J (2017) Activated Sludge Separation Problems: Theory, Control Measures, Practical Experiences. IWA Publishing, London, UK.

Thomas P (2011) The effects of food waste disposers on the wastewater system: a practical study. Water and Environment Journal 25(2): $250-256$

Williams M, Kookana RS, Mehta A et al. (2019) Emerging contaminants in a river receiving untreated wastewater from an Indian urban centre. Science of the Total Environment 647: 1256-1265.

Yilmaz T, Yucel A, Cakmak Y et al. (2019) Treatment of acidic mine drainage in up-flow sulfidogenic reactor: metal recovery and the $\mathrm{pH}$ neutralization. Journal of Water Process Engineering 32: 100916.

\section{How can you contribute?}

To discuss this paper, please email up to 500 words to the editor at journals@ice.org.uk. Your contribution will be forwarded to the author(s) for a reply and, if considered appropriate by the editorial board, it will be published as discussion in a future issue of the journal.

Proceedings journals rely entirely on contributions from the civil engineering profession (and allied disciplines). Information about how to submit your paper online is available at www.icevirtuallibrary.com/page/authors, where you will also find detailed author guidelines. 